\title{
Education is the Medium of Stable Society (In Islamic Perspective)
}

\author{
Prof Dr. Matloob Ahmad \\ Dean of Arts and Social Sciences, Head of Arabic \& Islamic Studies Department, The \\ University of Faisalabad. \\ Dr. Ammara Rehman \\ Assistant Professor Islamic Studies, The University of Faisalabad. \\ Dr. Aijaz Ali Khoso \\ Assistant Professor, University of Sufism and Modern Sciences, Bhitshah, Sindh.
}

Received on: 09-10-2021

Accepted on: 10-11-2021

\begin{abstract}
Education is very significance for all humanity. It starts from birth to last moment of life for all groups of populace instead of any distinction of Community, Belief, Rreligion and area. It is the way of gaining knowledge, worth, Expertise and any ethical values. The common person intense to take high kind of informatory of knowledge more than previous knowledge. Education is most important for each and every to upgrade fresh knowledge. It is the medium of stable society. It is source to gain good economic place in all the fields of life. The education is the right of every person which he gains it from his birth. Education presents the solution of all the personal and social issues of society. Education performs an important part in all disciplines of life. The Islam has also declared the education compulsory for any individual in order to pass life in a good and peaceful life. So, we want to be much educated. It changes us totally from inner and outer side of by replace our brain and character as well as better our belief level. It convert our life entirely as it is positive in the world. It is stable society by what he perform his duties as best way in the light of Islamic teaching.
\end{abstract}

Keywords: Education, Humanity, Community, Religion, Ethical Values, Issues.

\section{Introduction}

It helps a person gain knowledge and develop a level of confidence throughout life. It plays a key role in our growth in the workplace and in our personal growth. There are no limits; people of any age group can get an education at any time. It helps us to decide what is right and what is wrong. An educated person with a good education becomes a good citizen of the community. We all want to see our children go to success that can only be achieved with a good and proper education. Every parent tells his or her children from an early age the importance of education in life and all the benefits of education to make their minds focused on a better future. Get your children and your children accustomed to writing 
Vol. II, Issue 3, Oct - December 2021

ISSN No: (ONLINE): 2710-043

www.irjei.com
International Research Journal of Education and Innovation

ISSN No: ISSN (PRINT): 2710-0448

DOI: https://doi.org/10.53575/irjei.v2.03(21)4.44-52

\section{Education is the Medium of Stable Society (In Islamic Perspective)}

essays, participating in discussions and discussions and with many skills development activities at school or at home using such simple essays.

Islam has emphasized the importance of the acquisition and dissemination of knowledge ('ilm) more than any other human activity. In fact, it makes it compelling for its followers, without gender, to read and disseminate information. The obligation to seek knowledge is the obligation of all Muslims by the command of the Qur'an and the Sunnah of the Last Holy Prophet Muhammad (4). The concept of education in Islam should take into account all the dimensions of life and society. Education plays a vital role in Islamic civilization. The purpose of learning in Islam is to produce a righteous person who is able to perform his duties as a servant of Allah (abdullāh) and his vicegerent (khalīfah) in the world.

\section{Education Meaning}

"The word Education is derived from language of Latin which means Educatum" (1). "In another book the meaning of the education is Educare which means understanding and makes practice". (2)

But the meaning of education in Arabic language is described as:

"Arabic language defines three etymological meaning of education. Ta'lim from the root 'alima (to know, to be aware, to perceive, to learn) which is used to denote knowledge being sought or imprinted through instruction and teaching.Tarbiyah from the root raba (to increase, to grow, to rear) implies a state of spiritual and ethical nurturing in accordance with the will of God. And Ta'dib from the root aduba (to be cultured, refined, well-mannered) suggests a person's development of sound social behavior. What is meant by sound requires a deeper understanding of the Islamic conception of human being.The universally accepted meaning of education today is growth, i.e. continuous unfolding of one's potentialities; it is a life-long process". (3)

The Holy Prophet Muhammad ( Said:

$$
\text { "اطلبوا العلم من المهد إلى اللحد" (4) }
$$

"Acquiring knowledge from the cradle to the grave"

The different thinker define education as:

"Education is the mean that helps in searching the truth. And Education is a process necessary for the creation of sound mind in the sound body". (5)

"Education is a process which enables an individual to distinguish between the true and the false, the good and bad and the right conduct and the evil doing" (6).

"It as a device to fit a man to perform justly, skillfully and magnanimously all of the offices, both private and public, peace and war". (7)

World book of "encyclopedia denotes education as the process by which people acquire knowledge, skills, habits, values or attitudes."(8)

The Holy Quran Said:

$$
\text { "وما كان المؤمنون لينفروا كآفة فلولا نفر من كل فرقة منهم طآئفة ليتفقهوا في الدين و لينذروا قومهم اذا رجعوا اليهم لعلهم يحذرون"(9) }
$$

"It was not necessary for the believers to go forth all together (to receive religious instruction), but why did not a party of them go forth that they may grow in religious understanding, and that they may warn their people when they return to them, so that they may avoid (erroneous attitudes)."

In Islam, learning of education is the main part and parcel of any human being. The education 
Vol. II, Issue 3, Oct - December 2021

ISSN No: (ONLINE): 2710-043

www.irjei.com
International Research Journal of Education and Innovation

ISSN No: ISSN (PRINT): 2710-0448

DOI: https://doi.org/10.53575/irjei.v2.03(21)4.44-52

\section{Education is the Medium of Stable Society (In Islamic Perspective)}

decorates the man with good spiritual capacity and increases in the store of knowledge and assists in knowing his Creator. Education tells about the difference between the goodness and the evil. Whereas an educated person can know about the main objectives of his creation. The Holy Quran said:

$$
\text { "وما خلقت الجن والإنس إلا لعبدون 10) }
$$

"And I did not create the jinn and mankind except to worship Me"

On the other hand an Islamic Education is stated as:

"A thinking system, directly or indirectly, originating from the Islamic values. Several scholars defines Islamic education as the rearing and formation of an ideal Muslim individual whose life is brought to bear on the Islamic ideal in his different bodily, intellectually and mentally. The content and methods of his education being closely bound by the ideology of Islam. Identifies Islamic education as a group of practical and verbal actions inspired by knowledge of the Quran and Sunna and based on them in matters to do with faith". (11) This thinking is also found in the saying of the Last Holy Prophet Muhammad (SAAW).

$$
\text { "من يرد الله به خيرا يفقهه في الدين"(12) }
$$

"If Allah intends goodness for someone, he gives him understanding of the religion". This Hadith explained the significance of knowledge and understanding. The Holy Prophet

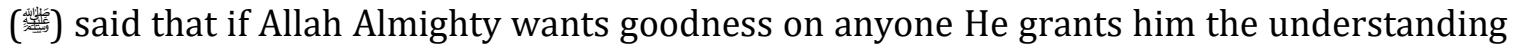
of Deen.It is clear that education and understanding main needs of any human beings. So the lesson is to gain knowledge is compulsory for men.

\section{Stable Society Needs Education}

A stable and balanced society is the capital need of human being. An educated man can spend his life in society with rest, satisfaction, mannered and discipline life only with education. A qualified educated person can live with complete confidence in society. He is supposed to be a disciplined and well behaved person.

Education learning has been stated again and again in Islam and its needs and fruits. Because the qualified person knows the concepts of rights of man and woman. He knows the importance of Law making and its implementation. The educated person can run well business for the growth and progress of the society. Its mean that education person can play an important role for the building of stable society. So, the importance of the education has been also described in the First revealed verses of the Holy Quran which are the following:

$$
\text { "اقرا باسم ربك الذى خلق خلق الانسان من علق اقرا وربك الاكرم الذى علم بالقلمّ علم الانسان ما لم يعلم"(13) }
$$

"Read! In the Name of your Lord who has created (all that exists). He has created man from a clot (a piece of thick coagulated blood). Read! And your Lord is the Most Generous. Who has taught (the writing) by the pen. He has taught man that which he knew not. "

These are first revealed verses of Holy Quran in which importance of the knowledge and education has been described. In these verses it has been emphasized again and again that the education is compulsory for the humanity. On another place the Holy Quran Said:

$$
\text { "رب زدني علما"(14) }
$$

"My Lord! Increase me in knowledge"

The above stated verse expressed the main significance of knowledge (Ilm).In this verse The Holy Prophet Muhammad (") always prayed as "My Raab you may always increase my 
Vol. II, Issue 3, Oct - December 2021

ISSN No: (ONLINE): 2710-043

www.irjei.com
International Research Journal of Education and Innovation

ISSN No: ISSN (PRINT): 2710-0448

DOI: https://doi.org/10.53575/irjei.v2.03(21)4.44-52

\section{Education is the Medium of Stable Society (In Islamic Perspective)}

knowledge" So its mean that the knowledge and education is very mandatory for men and society.

$$
\text { "خيركم من تعلم القرآن وعلمه"(15) }
$$

"The best of you are those who learn the Quran and teach it".

Allama Al Qartabi a well-known learner personality states importance of this Hadith. He explained that The Holy Prophet Muhammad (4 has given the basis of Islamic education system. This sound education is needed for the religion. Every person can understand religion and its given system with the sound knowledge. The main source of knowledge in the Holy Quran and due to this reason The Holy Prophet Muhammad (4tared the best one person who learns the Quran. So, the first stage of knowledge and education is to construct the relations of human beings and with his Creator.

The Holy Prophet Muhammad (the learning and understanding the main source of education that is the Holy Quran. The Holy Quran also explained that education and knowledge only comes by the learning with full commitment and those scholars are only who fear from Allah Almighty among the people. The Holy Quran stated this thinking as following:

"يا أيها الناس إنما العلم بالتعلم والفقه بالثفقه ومن يرد الله به خيرا يفقهه في الدين وإنما يخشى الله من عباده العلماء"(16

"O people, knowledge only comes by learning and understanding only comes by seeking understanding. For whomever Allah intends good, he gives him understanding of the religion. Verily, only those with knowledge fear Allah among his servants".

Education gives the dedication in the direction of the fundamental values which have been prescribed in faith and revealed books. It also emphasizes on the sense of duty in the direction of Allah Almighty. So, that individual can spent their lives as an obedient person.In the above verse of the holy Quran it is clarify that knowledge only comes by gaining and to understand to it. The religion also plays an importance role to learn the knowledge. The followers of religion always try their best to gain the education. So. The importance of the beneficial knowledge describe in following hadith.

$$
\text { "إذا مات الإنسان انقطع عنه عمله إلا من ثلاثة إلا من صدقة جارية أو علم ينتفع به أو ولد صالح يدعو له"(17) }
$$

"When the human being dies, his deeds end except for three: ongoing charity, beneficial knowledge, or a righteous child who prays for him".

The Holy Prophet Muhammad ( of fruitful knowledge and education. He stated that the beneficial knowledge will give relief to a deceased person in all his life of hereafter. So, this is great proof that any person who gained education and his education is beneficial for the people and society. He would be in the life of rest ness after his death.

\section{Origins of Islamic Education}

Islamic education plays an important role to construct a stable society and its balanced system. The Islamic education depends upon of its sources. The sources of this education are

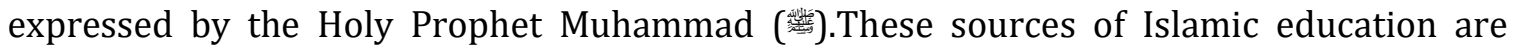
declared by the Holy Prophet Muhammad ( (twe Sunnah of his prophet . This is stated in this following Hadith: 
Vol. II, Issue 3, Oct - December 2021

ISSN No: (ONLINE): 2710-043

www.irjei.com
International Research Journal of Education and Innovation

ISSN No: ISSN (PRINT): 2710-0448

DOI: https://doi.org/10.53575/irjei.v2.03(21)4.44-52

Education is the Medium of Stable Society (In Islamic Perspective)

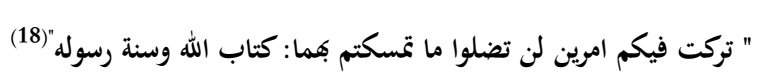

"I have left two matters with you. As long as you hold to them, you will not go the wrong way. They are the Book of Allah and the Sunna of His Prophet."

Islamic Education is derived from Islamic values which are found in the Holy Qur'an and it is explained by the various saying and deeds of The Last Holy Prophet Muhammad ( As such they are considered as final and unchangeable. The Holy Quran stated as: "عaught " "علم القرآن" "Taught the Quran"

The Holy Quran contains all knowledge and The Last Holy Prophet Muhammad (4-) practically enunciated, instructed and implemented this knowledge .He also showed the right path how to lead any one's life in a perfect way. Islamic education is the ever -increasing accumulation of pure scientific knowledge gained through the application of the human mind and sensual powers on the material environment surrounding man. So, the Holy Quran also contains scientific indication and philosophical thought. This thinking all the Holy Quran will be only followed when every person protects of the right of other. Because the Islam emphasized on the security of the rights of every human beings. So, the Holy Quran explained this meaning in the following verse.

$$
\text { " وتوا صوابا لحق" "20) }
$$

"And urge each other to the truth (Haq)".

The Holy Quran Said to adopt the pattern the life of the Holy Prophet as model:

$$
\text { "لقد كان لكم في رسول الله أسوة حسنة لمن كان يرجو الله واليوم الآخر وذكر الله كثيرا"(21) }
$$

"Ye have indeed in the Messenger of Allah a beautiful pattern (of conduct) for any one whose hope is in Allah and the Final Day, and who engages much in the Praise of Allah".

The same is about other states and religions, who want to transfer their cultures to the next generation.

Education is very powerful social change agent through which a particular society's social, religious, and political setups are changed. If there exists some out dated cultural values, formal and informal education is carried out in order to bring the desired change. Which ultimately leads to social change with the help of knowledge having understanding. The Quran Said:

$$
\text { " إن الله لا يغير ما بقوم حتى يغيروا ما بأنفسهم "(22) }
$$

"Verily Allah does not change a people's condition unless they change their inner selves".

The Holy Quran explained this reality that Allah Almighty does not change the condition of those persons who do not want to gain changings from their inner sides. So, this is the main lesson that every citizen of the state should have change himself in the form of sustainable development of the society and states. Its meaning is this that we should work hard for the progress of humanity and society to change our habits of negligence, ignorance, and laziness. So, the developed society can be come in existence only for having education. The process of learning the education is very important for the progress of any society. Due to this reason the Holy Prophet explained the benefits of the education in the following Hadith.

$$
\text { "ما من خارج خرج من بيته في طلب العلم إلا وضعت له الملائكة أجنحتها رضا بما يصنع"(23) }
$$

"No one leaves their house in search of knowledge but that angels will lower their wings in approval of what he is doing". 
Vol. II, Issue 3, Oct - December 2021

ISSN No: (ONLINE): 2710-043

www.irjei.com
International Research Journal of Education and Innovation

ISSN No: ISSN (PRINT): 2710-0448

DOI: https://doi.org/10.53575/irjei.v2.03(21)4.44-52

\section{Education is the Medium of Stable Society (In Islamic Perspective)}

The importance of gaining the knowledge is expressed by The Holy Prophet. It is said that the person who leaves his residence place in search of knowledge. He is awarded with the blessings of Allah Almighty. In other teachings, the Holy Prophet declared, that knowledge is good which is beneficial for person himself and for other individuals. This thinking is stated in the following Hadith:

$$
\text { "اللهم إني أعوذ بك من علم لا ينفع ومن قلب لا يخشع ومن نفس لا تشبع ومن دعوة لا يستجاب لها"(24) }
$$

"O Allah, I seek refuge in you from knowledge that does not benefit, from a heart that is not reverent, from a soul that is not content, and from a supplication that is not answered"

From the above Hadith it is clear that the education and the knowledge is good for an educated person who serves and used his knowledge for benefits and welfare of humanity. So, for an educated persons it is very compulsory that they should think about the development and progress for the Society and Humanity. It can be said that qualified members of the society can gain the aim of strong and stable society through their good educational activities.

The Quran said that the educated and non-educated persons are not equal.

$$
\text { "قل هل يستوى الذين يعلمون والذين لا يعلمون "(25) }
$$

"Ask them: "Are those who know equal to those who do not know?"

Education is a way in which any individual shares, having all directions of the reasoned, Psychological, and social angles. It gives the vast access to gain an educated society which is instructed to the "balanced growth of the total personality of an individual through training Man's spirit, intellect, rational self, feelings and bodily sense. Such that faith is infused into the whole of his personality".

It is non to the above the verse of the Holy Quran that the educated people are preferred on the non-educated. The lesson of the Holy Quran through light that gaining the education knowledge is very mandatory for each person. Because with having the education. A person can serve the society and community with the best way. The Holy Quran is the best source of Education, due to this reason the learning the Holy Quran is appreciated and encouraged in the following Hadith.

$$
\begin{aligned}
& \text { "ومن سلك طريقا يلتمس فيه علما سهل الله له به طريقا إلى الجنة وما اجتمع قوم في بيت من بيوت الله يتلون كتاب الله ويتدارسونه بينهم }
\end{aligned}
$$

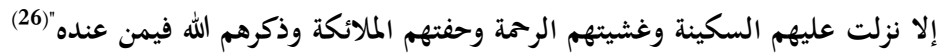

"Whoever travels a path in search of knowledge, Allah will make easy for him a path to Paradise. People do not gather in the houses of Allah, reciting the book of Allah and studying it together, but that tranquility will descend upon them, mercy will cover them, angels will surround them, and Allah will mention them to those near him".

It is appearing for the above Hadith that the actual source of Knowledge is Holy Quran and Hadith Nabwi. The Last Holy Prophet clarify that the learning, Teaching, Understanding, restitution and communication of teachings of the Holy Quran are a source of blessing of Allah Almighty. In the place where the discussion of the contents of the Holy Quran has been taken place, and that place the angels come for hearing the lesson of the Holy Quran. So, I t can be said that the learning and teaching of the Holy Quran us the best way for preaching. It means that the Holy Quran is a capital source of education and bother source of Holy Quran.

In International level, all world accepts that education is a capital medium for the advancement for each society therefore, the International of organization has expressed the 
Vol. II, Issue 3, Oct - December 2021

ISSN No: (ONLINE): 2710-043

www.irjei.com
International Research Journal of Education and Innovation

ISSN No: ISSN (PRINT): 2710-0448

DOI: $\underline{\text { https://doi.org/10.53575/irjei.v2.03(21)4.44-52 }}$

\section{Education is the Medium of Stable Society (In Islamic Perspective)}

significance of education for each community through their conferences seminar and conventions.

So, the United Nation High Commissioner for Refugees (UNHCR) has given the direction for compulsory education as following:

"Thus, it is obligatory for governments, international institutions and civil society organizations to work on, and advocate for the availability of quality educational opportunities that are accessible to all. The right to education is paramount and part of the inherent dignity of all humans; it is a tool to facilitate communication and bring cooperation among societies and, by extension, a means of bringing peace, stability and more mutual understanding between communities and nation."(27)

The World generation highlights schooling as a humanity right and acknowledges it as a need for complete, durable improvement for each qualified and developed Society. Education is source for financial and social improvement for any society and generation. The majority of people desires to promote the growth of society by enhancing social and monetary conditions inside world's poorest nations, this consist of selling usual number one training and getting to rid gender disparities in schooling education.

On the other hand, Islam also teaches that the Muslim has the duty to contribute the society and its human beings and all would be questionable for their ruling. This would only possible if everyone should follow the rules and regulations of the Islamic judicial system because Islamic judicial system is very important and beneficial for restness and social good interaction. "In Islam, justice is a sacred principle in all matters from personal relations to matters of governance. Justice is instrumental in fighting poverty and inequality and is vital in the achievement of sustainable development which is only possible for having education. Because justice entails protecting individuals' rights, as well as the fair distribution of wealth and resources. Justice is a human value in Islam; ignorance and illiteracy would prevent the performance of justice as it is taught in the Qur'an and the hadiths of the Last Holy Prophet Muhammad ( Therefore, knowledge and wisdom are paramount for the achievement of justice and social harmony in Islam"(28).

So, it is very clear that the knowledge of the Quran and the dissemination of its teachings is very beneficial for the stable society and for its members in all fields i.e Social, Political, Economic and others. It is also be expressed in the verses of the Holy Quran that the knowledge and understanding of the Quran for Muslims is much good. The Holy Quran Said:

$$
\text { "يؤتى الحكمة من يشآء تومن يؤت الحكمة فقد اوتى خيرا كثيرا وما يذكر الآ اولوا الالباب"(29) }
$$

"He grants wisdom to those whom He wills; and whoever is granted wisdom has indeed been granted much good. Yet none except people of understanding take heed".

"If anyone acquires knowledge of things by which Allah's good pleasure is sought, but acquires it only to get some worldly advantage, he will not experience the arf, i.e. the odour, of Paradise".(30)

The Holy Prophet states that all the process of learning will be for gaining the pleasuring of Allah and service for humanity.

In Islam, the responsibility of searching education and gaining is mandatory for all Men of Islam. Islam declares the right to gain the knowledge for each exempting any gender distinction. The Holy Quran states and expresses that all individuals will be checked by their education and consideration. 
Vol. II, Issue 3, Oct - December 2021

ISSN No: (ONLINE): 2710-043

www.irjei.com
International Research Journal of Education and Innovation

ISSN No: ISSN (PRINT): 2710-0448

DOI: https://doi.org/10.53575/irjei.v2.03(21)4.44-52

\section{Education is the Medium of Stable Society (In Islamic Perspective)}

The Islamic teachings also emphasized on the women's education too. Similarly The Holy Prophet encouraged those Muslims who try their best to educate to slave girls. This is stated in this Hadith.

$$
\text { " أيما رجل كانت له جارية فأدبها فأحسن تأديبها، وأعتقها وتزوجها، فله أجران، وأيما عبد أدى حق الله وحق مواليه، فله أجران(31) " }
$$

"He who has a slave-girl and teaches her good manners and improves her education and then manumits and marries her, will get a double reward; and any slave who observes Allah's right and his master's right will get a double reward."

This thinking was followed to abolish slavery in the early period of Islam, but at the same time shows the significance of Female learning in the final thought of the Last Holy Prophet Muhammad. In Islam, Well-being the of orphans is also advised. Muslims are motivated to give for the physical, social, and necessity of orphans.

Furthermore, the principles of charity in Islam offer a way through which Muslims can support education programs that will empower the disadvantaged sections of society. "Waqf, apart from zakat and sadaqah, is one way that Muslims engage in ongoing charity (Sadaqa Jareyah). Waqf can be in the form of paying for or declaring a building or land as a communal space, with schools ,Colleges, other educational institute and training centers falling within this category. Thus, Islam offers many forms of charity that Muslims can observe in order to promote education projects for the disadvantaged territories in developing countries".

\section{Conclusion}

Islam has an entire view of human Improvement, which sees training and information as crucial. Islam encourages the acquisition of understanding and its use for the gain of humanity similarly the standards of justice, equality, and equality to Islam, this consist of gaining expertise, expertise and skills tom perform one duties. While understanding is wanted to satisfy religious and religious responsibility, it is very vital in gratifying it. Social and financial improvement, social welfare, and the promotion of social cohesion, freedom and human rights in a strong society. The Qur'an and hadith suggest that information and education are vital for all Muslims for you to fulfill their obligations and responsibility to Allah and humanity. It is miles, consequently, clear that get admission to fact and providing identical get right to entry to education for all sections of society is of paramount significance in Islam. While the point of interest on economic and social development is vital for global improvement business, Islamic-based totally groups focus greater on relief work than on long-term period improvement initiatives, So that it will include training.

As shown above, both the purchase and provision of statistic is compulsory in Islam. Therefore, FBOs Muslims must keep in the mind the focus schooling as an obligation when setting priorities. Further, training for marginalized organization including women and contribution disadvantaged sections of society need to be prioritized in mission making planes. Calls from international institutions and Islamic teachings make it vital for FBOs for Islam to attention offering access to great training for all as part of their goals, particularly in those areas that are maximum in wants such as many growing countries. To be a supporter of Allah, guy is taught a way to manage his spiritual and political affairs in the world as a means of pleasing the cause of his advent in accordance with the suitable will of the Creator. It occupies an essential region in Islamic civilization. In Islam, information could handiest be found out via training is a requirement of faith and development in society and humanity. 
Vol. II, Issue 3, Oct - December 2021

ISSN No: (ONLINE): 2710-043

www.irjei.com
International Research Journal of Education and Innovation ISSN No: ISSN (PRINT): 2710-0448

DOI: https://doi.org/10.53575/irjei.v2.03(21)4.44-52

\section{Education is the Medium of Stable Society (In Islamic Perspective)}

\section{References:}

1) Al-Attas, Syed Muhammad al-Naquib, The Concept of Education in Islam, Petaling Jaya: Malaysia, 1980).

2) Rosenthal, Franz, Knowledge Triumphant: The Concept of Knowledge in Medieval Islam Leiden:E.J. Brill, 1970.

3) Syed Sajjad Hussain and Syed Ali Ashraf, Crisis in Muslim Education Jeddah: King Abdul Aziz University, 1979.

4) Ibid

5) Ajijola, Alhaji A.D., Re-Structuring of Islamic Education Delhi: Adam Publishers \& Distributors, 1999.

6) Muhammad Noor, Comprehensive Education in Islam, Comparative Ethics in a Global Age, edited by Marietta T. Stepanyants.

7) Al-Ghazzali, AbuHamid, Ihya' 'Ulum al-Din, Cairo, Al-Matba'ah al- Azhariyyah, 1898.

8) Khan, Mohammad Wasiullah, Education and Society in the Muslim World, Jeddah, King Abdul Aziz University, 1981.

9) Al Quran 9:122

10) Al Quran 51:56

11) Sarwar, Ghulam, Islamic Education: The Muslim Educational Trust, July 1996.

12) Șahīḥ al-Bukhāri 71.

13) Al Quran 96:1-5

14) AlQuran 20:114

15) Șahịḥ al-Bukhārī 4739.

16) Ibid $1: 72$

17) Șahịh Muslim 1631.

18) Almuwatta Imam Malik 24:331

19) Al Quran $55: 2$

20) Al Quran 103:3

21) Al Quran 33:21

22) Al Quran 13:11

23) Sunan Ibn Mājah 226.

24) Șahīḥ Muslim 2722.

25) Al Quran 39:9

26) Șahīh Muslim 2699.

27) UNHCR 1966.

28) Sarwar, Ghulam, Islamic Education: The Muslim Educational Trust, July 1996.

29) Al Quran 2:269

30) Sunan Abu-Dawud, 365

31) Sahi Bukhari 2547. 